Akreditasi KEMENRISTEKDIKTI, Nomor: 148/M/KPT/2020
http: / /jurnal.stkippersada.ac.id/jurnal/index.php/VOX

\title{
ANALISIS EFEKTIVITAS METODE ROLE PLAY PADA KEMAMPUAN MENDENGAR DAN BERBICARA BAHASA MANDARIN
}

\author{
Noval Rianti Salim \\ Progam Studi Bahasa Mandarin, Sekolah Tinggi Bahasa Harapan Bersama \\ Email:_novalfang@gmail.com
}

\section{INFO ARTIKEL \\ Riwayat Artikel: \\ Menerima : 04 Januari 2021 \\ Revisi : 08 Maret 2021 \\ Diterima :08 April 2021}

Kata Kunci:
Penerapan, Role play,
Bahasa Mandarin

Keywords:

Application, role play,

Mandarin

Korespondensi:

Noval Rianti Salim

Progran Studi Bahasa

Mandarin, Sekolah Tinggi

Bahasa Harapan Bersama

Email:

novalfang@gmail.com

\begin{abstract}
ABSTRAK
Penelitian ini bertujuan untuk mengetahui efektifitas metode role play, peningkatan skill speaking dalam bentuk dialog, dan mengevaluasi kesulitan yang dihadapi mahasiswa dalam penerapan metode role play. Penulis melakukan pengamatan dan analisis terhadap pembelajaran di kelas pada mahasiswa semester 1 program studi bahasa Mandarin Sekolah Tinggi Bahasa Harapan Bersama. Penulis menggunakan metode penelitian deskriptif dengan pendekatan kualitatif. Pengumpulan data dilakukan melalui teknik observasi, dokumentasi, serta wawancara dengan dosen pengampu mata kuliah dan mahasiswa. Instrumen yang digunakan berupa catatan perkembangan hasil belajar mahasiswa dan catatan wawancara. Hasil penelitian ini menunjukkan bahwa mahasiswa menjadi lebih aktif dan termotivasi mengikuti pembelajaran dengan menggunakan metode role play dalam bentuk dialog. Kesulitan dihadapi oleh mahasiswa dalam penerapan metode role play adalah pelafalan, tata bahasa, dan kelancaran dalam berbicara bahasa Mandarin. Metode ini juga memberikan dampak positif, hal ini dapat dilihat adanya peningkatan nilai ulangan harian, meningkat sebesar 0.5 , dari nilai rata-rata 7.6 meningkat menjadi 8.1. Dilihat dari hasil penelitian dapat disimpulkan bahwa penerapan metode role play dalam bentuk dialog dapat digunakan sebagai salah satu metode yang efektif dan menarik untuk meningkatkan skill berbicara bahasa Mandarin.
\end{abstract}

\section{ABSTRACT}

This research aims to determine the effectiveness of the role play method, improve speaking skils in the dialogue, and evaluate the difficulties faced by students in implementing dialogue, and evaluate the difficulties faced by students in implementing the role play method. The author conducted observation and analyzes of classrom learning in semester 1 students of the Mandarin Language Study Program at Sekolah Tinggi Bahasa Harapan Bersama for two months. Data collection was carried out by means of observation, documentation, and interviews with lecturers and students. The author uses a descriptive research method with a qualitatice approach. The result of this study indicate that students become more active and motivated to participate in learning by using the role play method in dialogue. The difficulties faced by students in implementing the role play method are pronounciation, grammar, and fluency in speaking Mandarin. This method also has a possitive impact, it can be seen that there is an increase in the daily test value, an increase of 0.5, from an average value of 7.6 to 8.1. Judging from the research results, it can be concluded that the application of the role play method in the form of dialogue can be used as an effective and interesting method to improve speaking skills in Mandarin Languague. 


\section{PENDAHULUAN}

Bahasa mempunyai peran penting dalam kehidupan manusia, fungsi bahasa adalah sebagai alat komunikasi antar manusia untuk menyampaikan pikiran, gagasan, konsep atau perasaan. Bahasa memiliki fungsi tertentu yang digunakan berdasarkan kebutuhan seseorang, bahasa digunakan untuk mengekspresikan dirinya, oleh karena itu Bahasa memiliki fungsi yang beragam, Bahasa disebut sebagai alat komunikasi baik secara lisan maupun tertulis.

Bahasa Mandarin sebagai salah satu bahasa internasional telah digunakan oleh lebih dari satu miliar orang di seluruh dunia membuat penguasaaan bahasa mandarin menjadi sangat penting. Di zaman era globalisasi seperti sekarang ini telah membuat banyak masyarakat Indonesia sadar akan pentingnya mempelajari bahasa asing, termasuk bahasa Mandarin. Skill bahasa asing telah dijadikan sebagai suatu penunjang karir untuk memasuki dunia kerja. Kesadaran itu yang membuat banyak masyarakat Indonesia yang belajar bahasa Mandarin. Saat ini pelajaran bahasa Mandarin sudah menjadi salah satu mata pelajaran dari Taman Kanak-kanak sampai SMA, tidak terkecuali di tingkat universitas, Sekolah Tinggi Harapan Bersama Pontianak berdiri sejak 2006, merupakan sekolah bahasa Mandarin di Pontianak.

Menguasai keterampilan berbicara merupakan salah satu hal yang penting dalam pembelajaran bahasa Mandarin. Keterampilan berbicara tidak sebatas hanya mampu berbicara dalam bahasa Mandarin saja tetapi ada empat skill yang harus dikuasai. Pada mata kuliah
Menurut Weniyanti (2020) Kemampuan Mendengar dan Berbicara terdiri dari empat komponen, yaitu keterampilan mendengar/menyimak (listening skills), keterampilan berbicara (speaking skills), keterampilan menulis (writing skills), dan keterampilan membaca (reading skills), untuk menguasai suatu bahasa dengan baik maka keempat keterampilan ini harus ada dan merupakan satu kesatuan yang diperoleh dengan cara banyak praktek dan latihan.

Dalam mempelajari bahasa Mandarin model pembelajaran yang lazim diterapkan pendidik adalah model pembelajaran langsung dimana peserta didik belajar dengan mengamati, mengingat dan menirukan pendidik (Mintowati, 2017).

Model pembelajaran langsung dilakukan dengan beberapa tahap, yaitu : 1) Orientasi. Sebelum penyampaian materi baru, dosen akan memberikan kerangka pelajaran dan indikatorindikator yang akan dicapaikan. 2) Presentasi. Pada tahap ini dosen akan menyampaikan materi. 3) Latihan terstruktur. Pada tahap ini dosen akan memandu mahasiswa untuk latihan dengan metode latihan yang sudah disiapkan, tahap ini merupakan tahap yang penting karena memberikan umpan balik terhadap respon mahasiswa dan mengeroksi respon mahasiswa yang salah. 4) Latihan terbimbing. Pada tahap ini mahasiswa diberi kesempatan untuk berlatih sesuai isi materi yang sedang dipelajari, peran dosen mengamati dan memberikan bimbingan apabila diperlukan. 5) Latihan mandiri. Pada tahap ini mahasiswa diberi tugas dan 
mengerjakannya atau melakukan latihan secara mandiri.

Penulis melakukan observasi terhadap metode latihan role play pada mata kuliah Kemampuan Mendengar dan Berbicara. Tujuan metode role play adalah untuk meningkatkan keterampilan berbicara yang lancar dalam bahasa Mandarin, supaya penyampaikan ide atau isi pikiran dapat dimengerti oleh pendengar yang perlu diperhatikan adalah pelafalan, intonasi, dan penggunaaan kosa kata yang tepat dan benar.

Metode role play adalah simulasi tingkah laku dari orang yang diperankan, yang bertujuan untuk melatih kemampuan praktik berbahasa lisan. Menurut Yamin, bermain peran adalah metode yang meletakkan interalisasi antara dua siswa atau lebih tentang suatu topik atau situasi. Siswa melakukan peran masing-masing sesuai dengan pokok yang ia yakini (Yamin, 2007). Mereka saling berinteraksi satu sama lain, metode ini dapat digunakan saat mempraktikan materi baru.

Metode role play sangat cocok diterapkan untuk mengungkap makan teks dialog, dalam pembelajaran mahasiswa dilatih untuk lancar berbahasa Mandarin dengan memerankan tokoh-tokoh yang terdapat dalam suatu cerita, atau terkadang mahasiswa diminta untuk membuat dialog sesuai dengan materi yang sedang dipelajari, namun sebelum dipraktikkan, teks tersebut dikoreksi terlebih dahulu oleh dosen pengampu. Metode ini diterapkan supaya mahasiswa lebih aktif dan memahami tujuan akhir pembelajaran.
Untuk mengetahui kondisi penerapan metode role play, maka rumusan masalah sebagai berikut :

1. Bagaimana penerapan metode role play pada mata kuliah Kemampuan Mendengar dan Berbicara?

2. Bagaimana pengaruh metode role play terhadap kemampuan berbicara bahasa Mandarin pada mahasiswa?

3. Kesulitan apa yang dihadapi mahasiswa dalam penerapan metode role play?

Berdasarkan rumusan masalah yang tersebut, maka penelitian bertujuan untuk :

1. Mendeskripsikan penerapan metode role play pada mata kuliah Kemampuan Mendengar dan Berbicara.

2. Mendeskripsikan pengaruh metode role play terhadap kemampuan berbicara bahasa Mandarin pada mahasiswa.

3. Mencari kesulitan yang dihadapin mahasiswa dalam penerapan metode role play.

\section{METODE PENELITIAN}

Dalam penelitian ini, penulis menggunakan metode deskriptif. Melalui metode penelitian deskriptif penulis mendeskripsikan kemampuan berbicara bahasa Mandarin pada mahasiswa dengan menggunakan metide role play.

Penelitian ini menggunakan pendekatan kualitatif. Moleong (2011:4) menyatakan penelitian kualitatif adalah 
penelitian yang menghasilkan data deskriptif berupa kata-kata tertulis atau lisan dari orangorang dan perilaku yang dapat diamati. Menurut Sugiyono (Sugiyono, 2012) analisis data adalah kegiatan pencarian dan penyusunan data dari proses wawancara secara teratur, sehingga lebih mudah dimengerti dan hasil analisis data dapat lebih mudah diinformasikan kepada orang lain. Penulis mengumpulkan data dengan melakukan observasi penerapan metode role play dalam bentuk dialog untuk mengasah skill berbicara pada mahasiswa semester 1 Sekolah Tinggi Harapan Bersama Pontianak. Instrumen yang digunakan berupa catatan perkembangan belajar mahasiswa. Jika hasil observasi menyatakan ada peningkatan kualitas pelafan dan kelancaran berbicara, maka penerapan metode role play ini bisa dibilang sangat efektif. Untuk mengetahui keefektifan metode role play maka penulis melakukan tiga teknik pengumpulan data, yaitu observasi, wawancara terhadap dosen pengampu dan mahasiswa, serta memberikan ulangan praktik untuk mengetahui respon mahasiswa sebelum dan sesudah penerapan metode role play ini.

Sumber data dalam penelitian ini adalah mahasiswa semester 1 progam studi S1 bahasa Mandarin Sekolah Tinggi Bahasa Harapan Bersama tahun ajaran 2019/2020 yang mengikuti mata kuliah Kemampuan Mendengar dan Berbicara. Data berupa hasil observasi atau catatan selama proses pembelajaran dengan metode role play dalam bentuk dialog.
Penulis melakukan observasi kelas dilakukan selama 2 bulan dan wawancara terhadap dosen pengampu dan mahasiswa. Penulis merupakan salah satu dosen pengampu mata kuliah Kemampuan Mendengar dan Berbicara, maka lebih mudah untuk mengamati dan melihat respon mahasiswa. Setiap mempelajari materi baru dosen pengampu akan memberikan latihan dengan menggunakan metode ini, dosen terlebih dahulu membagi kelompok yang terdiri dari 2-5 orang, mahasiswa diminta untuk membuat dialog percakapan terlebih dahulu, kemudian akan dikoreksi oleh dosen, supaya dosen dapat mengetahui sejauh mana penguasaan materi dan penggunaan kosa kata baru yang sedang dipelajari. Dosen pengampu mencatat respon mahasiswa kemudian ditulis dalam buku catatan, bagi mahasiswa yang tidak lancar dalam percakapan, akan diminta untuk lebih banyak berlatih dan di sesi pertemuan berikutnya akan diminta untuk tampil ulang.

Wawancara dilakukan terhadap 50 mahasiswa dan dosen pengampu yang bertujuan untuk mengetahui efektifitas penerapan metode role play, apakah selama 2 bulan penerapan metode ini ada pengaruh terhadap nilai mahasiswa, dan mencari tahu kesulitan apa yang dihadapi. Penulis juga akan memberikan tes dalam bentuk role play yang dilakukan pada sebelum dan sesudah penerapan metode ini, yang kemudian diberi nilai. Dari hasil nilai maka dapat diketahui bagaimana pengaruh penerapan metode role play dalam pembelajaran. 
Untuk memperoleh data penelitian, maka dilakukan beberapa instrumen penelitian sebagai berikut :

1) Observasi

Observasi adalah sebuah kegiatan pengamatan yang berhubungan dengan proses pembelajaran untuk mengetahui situasi dan kondisi suatu objek yang diteliti secara mendalam. Tujuan observasi adalah suatu cara mengumpulkan data untuk penelitian yang berhubungan dengan proses kerja atau proses studi yang objek penelitiannya tidak terlalu besar. Kegiatan observasi dilakukan untuk memantau aktivitas mahasiswa selama proses pembelajaran berlangsung ketika menggunakan metode role play dalam dialog.

2) Wawancara

Wawancara adalah kegiatan survey untuk mengumpulkan data atau informasi berhubungan dengan permasalahan diteliti. Proses wawancara terdiri dari dua pihak, pihak pertama sebagai interviewer, pihak kedua sebagai informan. Penanya akan mengajukan pertanyaan dan meminta informasi terkait, sambil mencatat di buku catatan, apabila penanya merasa ada informasi yang kurang, maka akan menggali keterangan lebih lanjut supaya mendapatkan informasi yang lengkap. Pihak informan diharapkan dapat kooperatif dalam memberikan informasi dan menjawab dengan jelas semua pertanyaan yang diajukan kepadanya.

3) Tes
Selama proses pembelajaran akan dilaksanakan test pada setiap materi baru yang bertujuan untuk mengetahui kemampuan berbicara mahasiswa dalam bahasa mandarin. Tes dilaksanakan dengan menggunakan metode role play ini, dosen pengampu akan mencatat hasil perkembangan, kesalahan, dan memberi nilai pada setiap mahasiswa.

\section{HASIL DAN PEMBAHASAN}

a. Hasil

Hasil yang diperoleh dari observasi selama 2 bulan pada mahasiswa semester 1 STB Harapan Bersama adalah sebagai berikut :

\section{Hasil Analisis Data Observasi}

Selama proses pembelajaran penerapan metode role play dalam bentuk dialog berjalan dengan lancar dan mahasiswa aktif dalam partisipasi. Dalam penerapan metode role play ini, dosen pengampu terlebih dahulu mendesain pembelajaran dengan membagi dalam beberapa kelompok secara random, setiap kelompok terdiri dari 3-4 orang. Masing-masing kelompok akan mendapatkan topik sesuai dengan materi sedang dipelajari saat itu. Berdasarkan hasil observasi penulis menemukan bahwa setiap minggu mempelajari bab baru. Materi yang sedang dipelajari saat itu adalah 你喜欢中餐还是西餐（apakah kamu menyukai masakan China atau masakan barat ). Selanjutnya masing-masing kelompok berdiskusi, menyusun naskah dengan menggunakan kosa kata yang dipelajari pada materi tersebut, setelah membuat naskah percakapan, mahasiswa mengumpulkan naskah 
kepada dosen, kemudian langsung diperiksa dan dikoreksi, naskah tersebut dikembalikan kepada mahasiswa lagi.

Pada tahap ini mahasiswa diberi waktu untuk berlatih bermain peran terlebih dahulu dengan tujuan ketika dipresentasikan bisa diucapkan dengan lancar dan benar. Setelah selesai latihan, dosen meminta beberapa kelompok untuk menampilkan hasil diskusi mereka dengan bermain peran dialog.

Berdasarkan hasil observasi, saat baru beberapa kali penerapan metode role play, penulis menemukan bahwa walaupun mahasiswa telah berlatih, namun ada beberapa mahasiswa yang masi kaku, belum lancar berbicara dalam bahasa Mandarin dan terjadi kesalahan pelafalan dan intonasi.

Ketika memasuki pertemuan ke 3 dengan judul topik 我搬家了(saya pindah rumah), mahasiswa mulai terbiasa dengan metode ini, mahasiswa kelihatan antusias dan bersemangat. Mahasiswa mulai lancar berdialog dalam bahasa Mandarin, tetapi kesalahan yang paling sering terjadi adalah pelafalan dan intonasi. Memasuki pertemuan ke 5 ada peningkatan dalam berdialog, mahasiswa mampu berdialog dengan lancar, pelafan yang tepat, serta semakin enjoy dalam peran yang dimainkan. Dari setiap pertemuan kemampuan mahasiswa semakin meningkat, mahasiswa lebih aktif berbicara bahasa Mandarin selama pembelajaran berlangsung.

\section{Hasil Analisis Data Nilai Tes}

mengetahui pengaruh metode role play terhadap kemampuan berbicara bahasa Mandarin pada mahasiswa, maka dilakukan tes berupa ulangan harian pada setiap kelompok. Tes dilakukan 3 kali selama 2 bulan observasi, dosen memberi tahu kepada mahasiswa akan ada ulangan harian pada pertemuan selanjutnya, sehingga mahasiswa dapat mereview materi yang sedang diperlajari. Dosen membagi kelompok secara random, mahasiswa dikasi waktu 10-15 menit untuk diskusi, setelah itu akan dipanggil untuk berdialog dengan metode role play. Mahasiswa berdialog dalam bahasa Mandarin secara spontan tanpa menghafal atau melihat teks, disini dosen dapat menilai kemampuan penyampaian dalam bahasa mandarin, pelafalan, intonasi, pemahaman penyampaian kalimat masing-masing peran, kelancaran, dan kekompakan kelompok.

Dilihat dari sebelum penerapan metode role play nilai semua mahasiswa adalah di atas angka 6 dengan rata-rata nilai 7,6. Setelah penerapan metode role play semua mahasiswa mendapatkan nilai di atas 7 dengan rata-rata nilai 8,1. Maka dapat dilihat bahwa ada peningkatan nilai sebesar 0.5. Melalui penerapan metode role play terjadi pengaruh terhadap peningkatan nilai mahasiswa.

3. Hasil Analisis Data Wawancara Dosen dan Mahasiswa

Penulis melakukan wawancara terhadap dosen pengampu, berdasarkan hasil wawancara terhadap dosen mengatakan metode role play terbukti efektif meningkatkan keterampilan berbicara, semakin semakin lancar dan lebih aktif berbicara dalam bahasa Mandarin. Mahasiswa juga terlihat antusias, tertarik dan semangat 
dalam mengikuti proses belajar. Namun, sejauh ini kesulitan yang dihadapi dosen pengampu adalah dalam melatih pelafalan, intonasi, dan tata bahasa yang digunakan, hal ini dikarenakan mahasiswa semester 1 merupakan mahasiswa yang baru belajar bahasa Mandarin dan banyak diantara mereka belum mempunyai kemampuan dasar bahasa Mandarin. Mereka belum masih kaku berbicara dan menggunakan tata bahasa bahasa Mandarin, sehingga ada beberapa mahasiswa ketika diminta berdialog masih kedengaran logat bahasa Indonesia dan kesalahan yang paling umum adalah menggunakan tata bahasa Indonesia ketika berdialog dalam bahasa Mandarin. Semakin diberi banyak latihan dengan metode role play, kesulitan yang dialami mahasiswa semakin berkurang.

Penulis juga melakukan wawancara terhadap mahasiswa dengan tujuan untuk mengetahui respon mahasiswa terhadap metode role play, maka dari hasil wawancara dapat diketahui mahasiswa mengaku menyukai metode ini, selama latihan bermain peran mahasiswa lebih aktif dan bagi mahasiswa yang belum begitu lancar merasa terbantu karena sering melakukan diskusi kelompok, serta mahasiswa terdorong untuk berbicara bahasa Mandarin selama proses pembelajaran. Judul topik yang sederhana juga memudahkan mahasiswa untuk berdialog, karena topik sederhana yang berhubungan dengan kehidupan sehari-hari dapat dipraktekan diluar jam pelajaran.
Berdasarkan hasil wawancara dengan dosen dan mahasiswa maka dapat disimpulkan metode bermain peran dalam bentuk dialog ini sangat perlu diterapkan untuk pembelajaran bahasa Mandarin, terutama untuk meningkatkan skill berbicara mahasiswa. Mahasiswa mengaku penerapan metode role play sangat menyenangkan, membuat mahasiswa menjadi termotivasi, suasana belajar lebih hidup, serta memudahkan untuk menyerap materi yang sedang dipelajari. Menurut (Anas, 2014: 52) metode bermain peran dapat memberikan siswa kesenangan dan suasana belajar yang menggembirakan.

b. Pembahasan

Berdasarkan hasil observasi dapat diketahui mahasiswa tampak aktif, antusias, suasana kelas menyenangkan, serta berpengaruh baik terhadap pembelajaran. Hasil data nilai ulangan harian sebelum dan sesudah penerapan metode role play, serta hasil wawancara dapat diketahui metode ini cocok diterapkan di mata kuliah Kemampuan Mendengar dan Berbicara, nilai mahasiswa cenderung meningkat setelah berlatih dengan metode role play.

Selama proses pembelajaran berlangsung menggunakan metode role play berupa dialog telah membantu mahasiswa untuk melatih skill berbicara dalam bahasa Mandarin

\section{SIMPULAN}

Berikut adalah kesimpulan dari penelitian yang dilakukan:

1. Penerapan metode role play dalam bentuk dialog pada mahasiswa semester 1 Sekolah Tinggi Bahasa Harapan Bersama Pontianak memperoleh hasil yang efektif dalam 
pembelajaran mata kuliah Kemampuan Mendengar dan Berbicara. Mahasiswa termotivasi dan aktif karena mahasiswa merasa semakin hari semakin lancar dalam berbicara bahasa Mandarin, sehingga membuat mahasiswa tidak merasa bosan dan semakin tertarik mengikuti mata kuliah ini.

2. Metode role play memberikan pengaruh cukup besar dan memberikan dampak positif, hal ini dapat dilihat dengan adanya peningkatkan nilai ulangan mahasiswa. Setelah penerapan metode role play nilai mahasiswa meningkat sebesar 0.5 , dari nilai rata-rata 7.6 meningkat menjadi 8.1.

3. Berdasarkan hasil obervasi dan wawancara terdapat beberapa kesulitan yang dihadapi mahasiswa dan dosen dalam penerapan metode role play, pada pertemuan awal mahasiswa merasa kesulitan dalam pelafalan dan intonasi, selain itu, mahasiswa belum terbiasa dengan metode latihan ini sehingga membuat mahasiswa merasa canggung dan susah untuk kerja sama dalam kelompok, mahasiswa awalnya merasa malumalu dan kurang percaya diri, namun dosen menyadari kendala tersebut, sehingga setiap pertemuan diberikan latihan dengan menggunakan role play, hasilnya mahasiswa sudah mulai percaya diri dan lancar berbicara dalam bahasa Mandarin.

Topik percakapan yang menarik dapat membuat mahasiswa lebih tertarik dan termotivasi untuk belajar, hal ini menjadi salah satu kesulitan yang dihadapin oleh dosen pengampu mata kuliah, sehingga dosen harus berupaya mencari topik percakapan yang diminati dan cocok untuk mahasiswa. Kesulitan yang lain adalah kesalahan pelafalan dan tata bahasa yang digunakan mahasiswa, dikarenakan mahasiswa semester satu dengan kemampuan bahasa Mandarin yang masih dasar belum terlatih menggunakan tata bahasa Mandarin. Setelah penerapan metode role play terjadi peningkatan pada mahasiswa, kesalahan-kesalahan tersebut semakin berkurang.

\section{DAFTAR RUJUKAN}

Mulyono. (2011). Strategi Pembelajaran: Menuju EfektivitasPembelajaran di Abad Global. Malang: UIN Maliki Press.

Selvianti. (2013). Peningkatan Kemampuan Siswa Mengungkapkan Makna dalam Monolog Bahasa Inggris Berbentuk Teks Prosedur melalui Metode Demonstrasi di Kelas X SMA Negeri 1 Kotabumu [21 Juni 2013]. Lampung: Unila.

Sugiyono. (2012). Metode Penelitian Kuantitatif, Kualitatif dan R\&D. Bandung: Alfabeta.

Weniyanti. (2020). Efektivitas Penggunaan Media Permainan Teks dalam Keterampilan Mendengar dan Berbicara Bahasa Mandarin.

Wijaya Mokhamad Erfan. (2017). Penerapan Metode Bermain Peran Dalam Bentuk Dialog Untuk Melatih Keterampilan Berbicara Bahasa Mandarin Siswa Kelas XI SMAN 2 Malang. [April 2017]. Malang .

Yamin Maritnis. (2007). Profesionalisme Guru dan Implementasi KTSP. Jakarta: Gaung Persada Press. 